\title{
Natural Pesticides and Future Perspectives
}

\author{
Ivana Cavoski ${ }^{1}$, Pierluigi Caboni ${ }^{2}$ and Teodoro Miano ${ }^{2}$ \\ 1'Istituto Agronomico Mediterraneo di Bari (CIHEAM-IAMB), Department of \\ Pharmaceutical Chemistry and Technology, University of Cagliari, \\ ${ }^{2}$ Dipartimento di Biologia e Chimica Agro-Forestale ed Ambientale, \\ Università degli Studi di Bari \\ Italy
}

\section{Introduction}

Biopesticide is a term that includes many aspects of pest control such as microbial (viral, bacterial and fungal) organisms, entomophagous nematodes, plant-derived pesticides (botanicals), secondary metabolites from micro-organisms (antibiotics), insect pheromones applied for mating disruption, monitoring or lure and kill strategies and genes used to transform crops to express resistance to insect, fungal and viral attacks or to render them tolerant of herbicide application (Copping \& Menn, 2000). Botanicals include crude extracts and isolated or purified compounds from various plants species and commercial products (Liu et al., 2006). Not unlike pyrethrum, rotenone and neem, plant essential oils or the plants from which they are obtained have been used for centuries to protect stored commodities or to repel pests from human habitations and use as fragrances, condiments or spices, as well as medicinal uses (Isman \& Machial, 2006). Quantitatively, the most important botanical is pyrethrum, followed by neem, rotenone and essential oils, typical used as insecticides (e.g. pyrethrum, rotenone, rape seed oil, quassia extract, neem oil, nicotine), repellents (e.g. citronella), fungicides (e.g. laminarine, fennel oil, lecithine), herbicides (e.g. pine oil), sprouting inhibitors (e.g. caravay seed oil) and adjuvants such as stickers and spreaders (e.g. pine oil) (Isman, 2006). Plants are capable of synthesizing an overwhelming variety of small organic molecules called secondary metabolites, usually with very complex and unique carbon skeleton structures (Sarker et al., 2005). By definition, secondary metabolites are not essential for the growth and development of a plant but rather are required for the interaction of plants with their environment (Kutchan \& Dixon, 2005).The biosynthesis of several secondary metabolites is constitutive, whereas in many plants it can be induced and enhanced by biological stress conditions, such as wounding or infection (Wink, 2006). They represent a large reservoir of chemical structures with biological activity. It has been estimated that 14 $28 \%$ of higher plant species are used medicinally and that $74 \%$ of pharmacologically active plant derived components were discovered after following up on the ethnomedicinal uses of the plants (Ncube et al., 2008). Plants and their secondary metabolites are an important source for biopesticides and the development of new pesticides. The recognition of the important role of these compounds has increased, particularly in terms of resistance to pests and diseases. The intensive use of synthetic pesticides and their environmental and toxicological risks have generated increased global interest to develop alternative sources of chemicals to be used in 
safe management of plant pests. Recently, in different parts of the world, attention has been paid towards exploitation of higher plant products as novel chemotherapeutics for plant protection because they are mostly non phytotoxic and easily biodegradable (Isman, 2006).

Currently, different botanicals have been formulated for large scale application as biopesticides in eco-friendly management of plant pests and are being used as alternatives to synthetic pesticides in crop protection. These products have low mammalian toxicity and are cost effective. Such products of higher plant origin may be exploited as eco-chemical and biorational approach in integrated plant protection programs (Dubey et al., 2009). In order to increase food safety and develop integrated and sustainable strategies for plant protection, which are safe to the consumer, producer and the environment, the use of natural pesticide need to be promoted. According to Ehlers (2009) in order to reach these goals we need less, rather than more registration requirements. Recently, Nthalli and Menkissoglu-Spiroudi (2011) reviewed the main chemical classes of plant secondary metabolites that have been used in crop protection focusing on the most recent advances in the chemicals disclosed, their mode of action and their fate in the ecosystem, their current use in pest management underlying registration procedures and commercialization potential. Numerous scientific articles, reviews and chapters book have been written on this subject. The main goal of this chapter is to review this actual topic on natural pesticides in a concise format that is easily understandable. Several topics will be emphasized and in particular: (1) the regulation of plant protection products from natural origin in European Union; (2) their regulation and importance in organic farming; (3) the actual State of art of three most widespread botanical pesticides: rotenone, azadirachtin and pyretrins and (4) the future perspectives of natural pesticides.

\section{Plant protection products from natural origins}

\subsection{Regulation in European Union}

Registration of Plant Protection Products (PPPs) based on botanicals, semiochemicals and micro-organisms follow rules originally developed for the risk assessment of synthetic chemical compounds. Data requirements for authorization and marketing of PPPs under Directive 91/414/EEC according to the categories are present in Table 1. Since PPPs can be harmful to humans and the environment their risks need to be evaluated and their active ingredients must be authorized according to Directive 91/414/EEC prior to commercial use. The authorization for commercial use is only given if unacceptable negative effects to humans and the environment can be excluded.

Biochemicals are the products that are intended for use in plant protection and can contain powdered plants parts, plant extracts and possibly co-formulants. While plant extracts are obtained by treating plants or parts of them, with a solvent, which is further concentrated through evaporation, distillation or some other process. Plant extracts can be obtained also by soft extractions with water and/or ethanol. All relevant available information must be presented in the summary dossier, and must be of sufficient quality to allow an assessment of possible risks of the proposed use. However supplementary data can be requested on a case-by-case basis by the competent authorities in order to allow finalizing the risk assessment. SANCO/10472 document contains a list of plants and plant extracts to which reduced data requirements should apply. Data required according to SANCO/10472 are: 1 . reference list established on the basis of available information including literature, evaluation done in OECD countries, European pharmacopoeia, and weight of evidence 


\begin{tabular}{|l|l|l|}
\hline Category of PPPs & $\begin{array}{l}\text { Description under } \\
\text { Directive 91/414/EEC }\end{array}$ & Data requirements given in \\
\hline $\begin{array}{l}\text { Biochemicals } \\
\text { (Plant extracts and plant } \\
\text { strengtheners) }\end{array}$ & Chemical substances & SANCO 10472 \\
\hline $\begin{array}{l}\text { Semiochemicals } \\
\text { (allelochemicals and } \\
\text { pheromones) }\end{array}$ & Chemical substances & OECD Series on Pesticides 12 \\
\hline $\begin{array}{l}\text { Micro-organism and } \\
\text { viruses }\end{array}$ & $\begin{array}{l}\text { Viable entities in scope of } \\
\text { Directive 91/414/EEC }\end{array}$ & $\begin{array}{l}\text { OECD Series on Pesticides 23 } \\
\text { Directives 2001/36/EC }\end{array}$ \\
\hline Macro-organisms & $\begin{array}{l}\text { Not covered by } \\
91 / 414 / \text { EEC }\end{array}$ & $\begin{array}{l}\text { OECD Series on Pesticides 21 } \\
\text { FAO and EPPO guidelines }\end{array}$ \\
\hline
\end{tabular}

Table 1. Categories of PPPs and data requirement for authorization and marketing under Directive 91/414/EEC

which indicates that the plant is not harmful to human, animal and environment, edible parts of plants used for animal or human feed herbal drugs in EU pharmacopoeia; 2. Description of the known active substances, providing the concentration range of any toxic substances that are relevant for human, animal health and environment, if the active substance (s) is (are) not identified the definition of a representative marker, providing analysis report of 5 batches of different manufacture, collected over several periods; 3 . Physico-chemical properties of all identified "active substances"; 4. Data regarding the application; 5. Validated analytical methods; 6. Efficacy data; 7. Residues in or on treated products food and feed; 8 . Fate and behavior in environment; 9. Ecotoxicological studies. Semiochemicals are chemicals emitted by plants, animals, and other organisms that evoke a behavioral or physiological response in individuals of the same or other species. They include pheromones and allelochemicals. Allelochemicals are semiochemicals produced by individuals of one species that modify the behaviour of individuals of a different species (i.e. an interspecific effect). They include allomones (emitting species benefits), kairomones (receptor species benefits) and synomones (both species benefit). Pheromones are semiochemicals produced by individuals of a species that modify the behaviour of other individuals of the same species (i.e. an intraspecific effect). Data required for semiochemicals are given in OECD Series on Pesticides 12 guidelines. Regarding microorganisms and viruses, data required are given in OECD Series on Pesticides 23 guidelines. In addition nematodes and macro-organisms are not covered by 91/414/EEC in most European countries (Denmark, Finland, France, Greece, Germany, Italy, Portugal and Spain) and usually no registration is required except for exotic species, which have never been used in biological control in an ecosystem. The regulation of plant protection products in the European Union (EU) was firstly harmonized under Directive 91/414/EEC, which came into force on 26 July 1993. This Directive established agreed criteria for considering the safety of active substances, as well as the safety and effectiveness of formulated products. It also provided the establishment of a positive list of active substances (forming 'Annex I' of the Directive) consisting of already existing and reviewed or new ones. A re-registration process was adopted for products already on the market containing a newly listed active substance in Annex I. The review of existing pesticides has led to the removal from the market of pesticides which cannot be used safely. Out of almost 1000 active substances commercialized on the market in at least one 
Member State before 1993, only $26 \%$, corresponding to about 250 substances, have passed the harmonized EU safety assessment. The majority of substances $(67 \%)$ has been eliminated because registration dossiers were either not submitted, incomplete or withdrawn by industry (Fig. 1.). About 70 substances failed to be reviewed and have been removed from the market, because the evaluation carried out did not show safe use with respect to human health and the environment. Regulation (EC) 1107/2009 (published on 24 November 2009) replaces Directive 91/414/EC and applies from 14 June 2011. It continues to harmonize plant protection products across the EU as well as introduces some new criteria for registration of plant protection products from plant origin as basic substances and low risk pesticides (Table 2, Fig. 1.). Active substances are considered as basic substances if they fulfill the criteria of the foodstuffs listed in Table 2. Low risk substances should not be considered if at least one of the criteria listed in Table 2 is satisfied. The substances which are currently listed in SANCO/10472 document, «25b list» of the US EPA and all substances with GRAS status reduced data are required for the registration. Some examples are listed in Table 3. In addition it will establish some new

European Directives

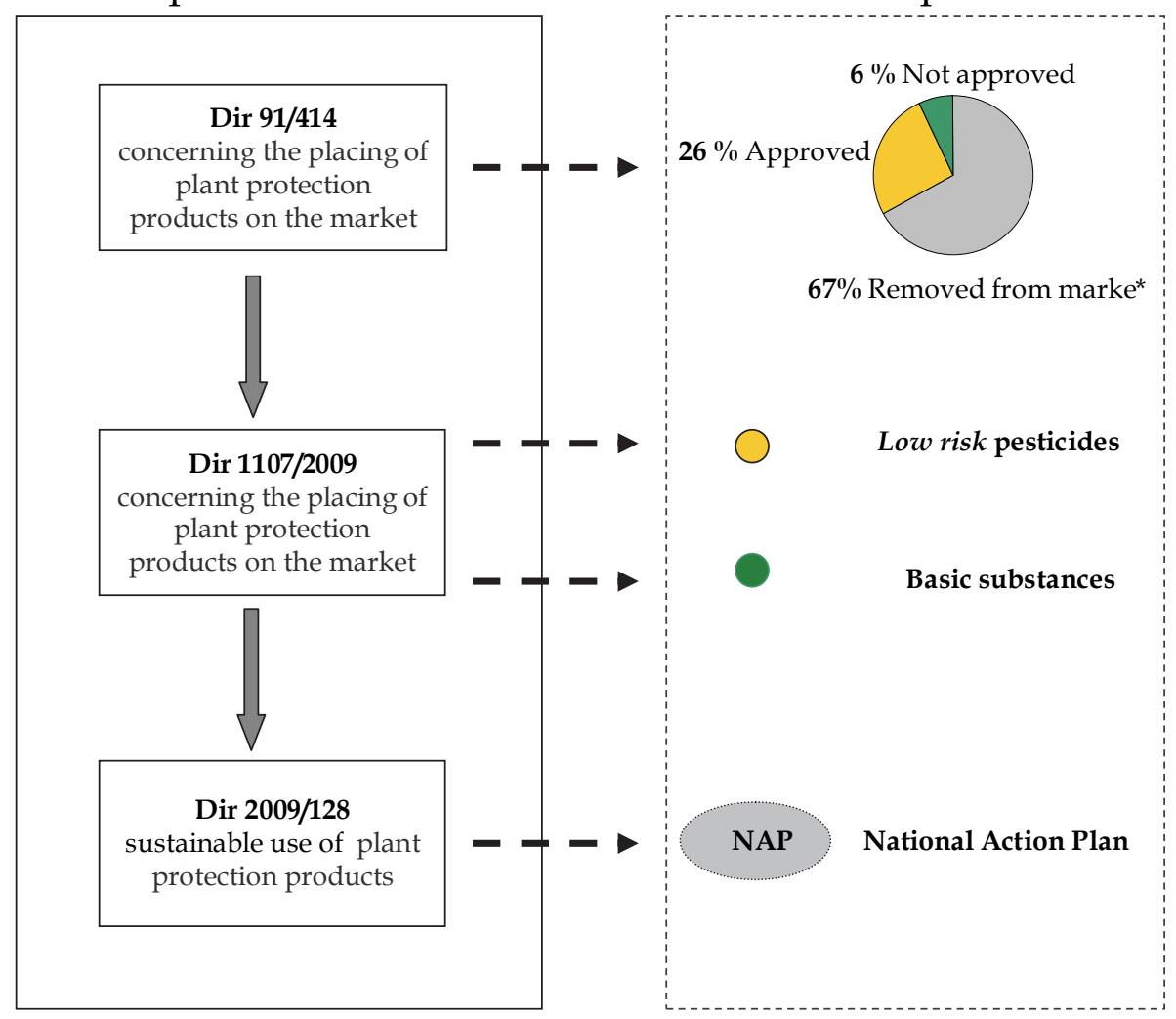

Fig. 1. EU regulations of plant protection products influencing the natural pesticides regulation ( ${ }^{*}$ no dossier submitted, incomplete dossier or dossier withdraw by industry) 


\begin{tabular}{|c|c|c|}
\hline $\begin{array}{l}\text { Basic substances } \\
\text { (fulfill the criteria of a 'foodstuff') }\end{array}$ & \multicolumn{2}{|c|}{$\begin{array}{l}\text { Low risk substances } \\
\text { (shall not be considered if at least of one) }\end{array}$} \\
\hline $\begin{array}{l}\text { a) is not a substance of concern } \\
\text { and }\end{array}$ & a) carcinogenic, & $\begin{array}{l}\text { f) persistent (half-life in } \\
\text { soil is more than } 60 \\
\text { days), }\end{array}$ \\
\hline $\begin{array}{l}\text { b) does not have an inherent } \\
\text { capacity to cause endocrine } \\
\text { disrupting, neurotoxic or } \\
\text { immunotoxic effects and }\end{array}$ & b) mutagenic, & $\begin{array}{l}\text { g) bioconcentration factor } \\
\text { is higher than } 100 \text {, }\end{array}$ \\
\hline $\begin{array}{l}\text { c) is not predominantly used a } \\
\text { plant protection product and }\end{array}$ & c) toxic to reproduction, & $\begin{array}{l}\text { h) it is deemed to be an } \\
\text { endocrine disrupter, or }\end{array}$ \\
\hline \multirow[t]{2}{*}{$\begin{array}{l}\text { d) is not placed on the market } \\
\text { as a plant protection product }\end{array}$} & d) sensitizing chemicals, & $\begin{array}{l}\text { i) it has neurotoxic or } \\
\text { immunotoxic effects. }\end{array}$ \\
\hline & e) very toxic or toxic, & \\
\hline
\end{tabular}

Table 2. Cutoff criteria for basic and low risk substances

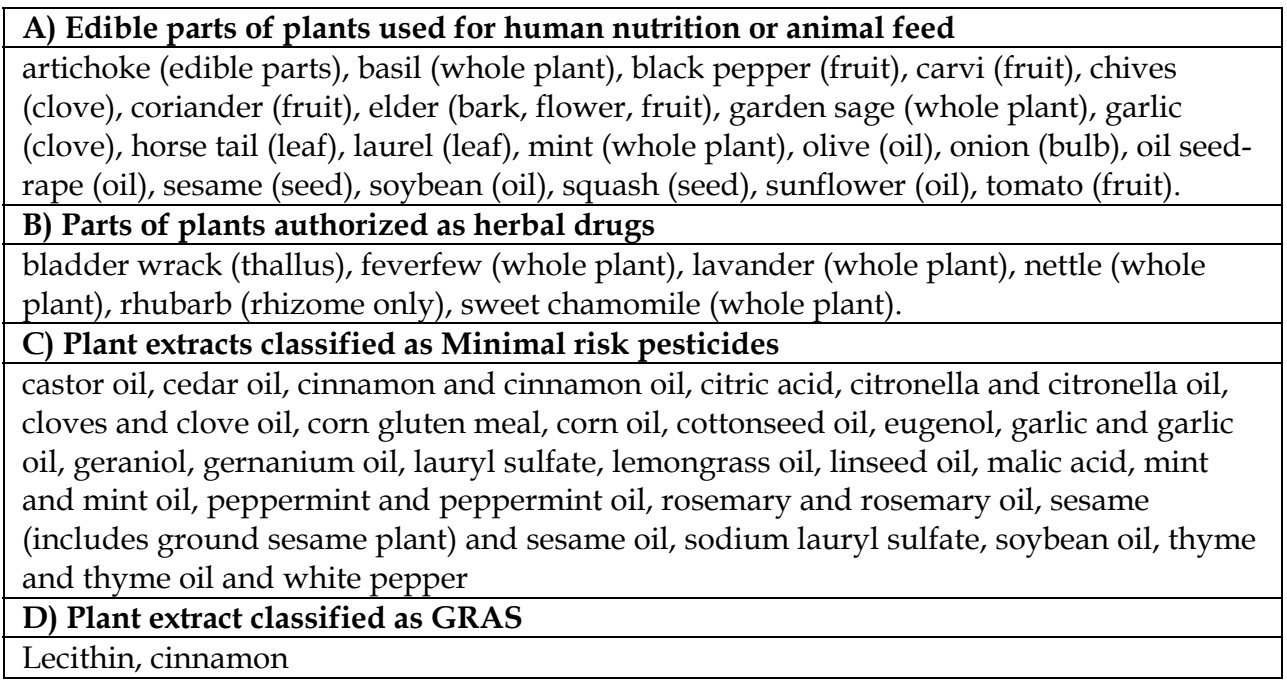

Table 3. Example of botanicals under the easier procedure for regularization: A) as listed in SANCO/10472; B) as listed in SANCO/10472; C) «25b list» of the US EPA; D) 21 CFR 184.1400 in the REBECA deliverable 14 (www.rebeca-net.de)

requirements, such as the introduction of hazard based criteria, assessment of cumulative and synergistic effects, comparative assessment and endocrine disruption. According to the new Dir 2009/128/EC on sustainable use of plant protection products Member states should adopt National Action Plans (NAP), set up their quantitative objectives, targets, measures and time table to reduce risk and impact of pesticides use on human health and the environment by 2012 and encourage the development and introduction of low inputs pesticide production giving whereas possible priority to non chemical methods. Low inputs pest management includes Integrated pest management (IPM) as well as alternatives methods like Organic farming, IPM must be implemented in each Member state by 2014 . 
Non chemical methods cover also biological pest control according to Dir 2009/128/EC . One example of NAP is a plane called "EcoPhyto2018" in France. The highlighted goals of Ecophyto 2018 are: "to achieve 50\% reduction in the use of pesticides by 2018, if feasible" and "that the total areas certified as organic agriculture go from the present $2 \%$ to $6 \%$ in 2012 , and eventually to $20 \%$ by $2020^{\prime \prime}$.

\subsection{Organic agriculture and EU regulations}

Organic agriculture is an ecological production management system that promotes and enhances biodiversity, biological cycles and soil biological activity. It is based on the minimal use of off-farm inputs and on management practices that restore, maintain and enhance ecological harmony (National Organic Standards Board, 1995). Ecological soundness is the key claim, indeed the raison d'être, of organic agriculture. Organic farming is a system approach aiming at a sustainable ecosystem, safe food, good nutrition, animal welfare and social justice. Since the beginning of the 1990s till 2009, organic farming has rapidly developed in almost all countries, with more than 37 million hectares managed organically by around 1.8 million producers, constitutes $0.85 \%$ of the agricultural area (FiBL/IFOAM Survey 2011). In 2009 the market value of organic products worldwide reached 60 billion U.S. dollars and consumption of organic vegetables and fruits has increased substantially in the last decade (Sahota, 2009). Quantitatively, organic farming is still of minor importance, but it is one of the most rapidly growing agricultural sectors worldwide. European organic food and drink sales are bouncing back from the economic slowdown in 2009 and while them will return to expand at higher growth rates from 2011 onwards. Growing consumer sophistication is leading to a proliferation in food eco-labels like organic, fair trade, biodiversity, carbon footprint, water footprint, etc. For many consumers, organic foods are the perfect example of quality and/or healthy and organic farming is 'farming without chemicals' (Lampkin 1990). Although there is some evidence that consumers are willing to pay more for environmentally 'added value' products such as organic produced foods (DEFRA, 2002; Gafsi et al., 2006) research shows that organic consumers are generally more interested in social and environmental aspects of food production than the average consumer (Sylvander \& François, 2006). The ethical concerns of organic consumers can be easily categorized according to the three pillars of the concept of sustainability: ecological, social, and economic sustainability. The concerns which exceed the standards set by the EU regulation 834/2008 on organic farming name "additional ethical" or "OrganicPlus" attributes (Zander et al., 2010). In 2004, the European Commission published an 'European Action plan for Organic Food and Farming' (COM, 2004), with the aim to facilitate the expansion of organic farming, to develop the market for organic food and improve standards by increasing efficacy, transparency and consumer confidence. The plan aims to achieve measures such as improving information about organic farming, streamlining public support via rural development, improving production standards or strengthening research. It follows the rapid increase in the number of farmers producing organically and strong demand from consumers during the past few years. The new EU 'organic regulation' consists of a framework regulation, complemented by implementation rules and guidelines. Other important regulations/standards are the National Organic Program of the USA, the guidelines of the Codex Alimentarius and the basic standards of the International Federation of Organic Agriculture Movements (IFOAM). Under all these standards, plant protection 
management and products are strictly regulated. Organic plant protection management follows a clear hierarchy, above all, plant health is maintained by preventative measures (choice of adapted species and varieties, crop rotation, cultivation techniques, thermal processes and the protection and/or release of natural enemies) and only if these methods are insufficient, plant protection products may be used (Speiser et al., 2006). The substances and their authorized uses are listed in Annex II of Reg. 889/2008 and divided in different categories as substances of crop or animal origin, micro-organisms used for biological pest and disease control, substances produced by micro-organisms, substances to be used in traps and/or dispensers, preparations to be surface-spread between cultivated plants, other substances from traditional use in organic farming, other substances. A very limited range of substances is authorized for use and for some authorized substances and only selected uses are allowed (Speiser et al., 2006). In the EU, new substances can only be authorized if they are consistent with organic farming principles, if they are necessary for sustained production, if they are of plant, animal, microbial or mineral origin in some cases exceptions are possible but non contact criteria has to be respected, if they have no harmful effects on the environment along the lifecycle and lowest negative impact on human or animal health and quality of life, with no negative socio-economic impacts or unfavorable public perception (Article 16 of Reg. 834/2007). In the EU, a legal definition of organic farming practices was first given in 1991 (EC, 1991) and regulations were developed in a lengthy process and represent a broad consensus in Europe (Schmidt \& Haccius 2008; Mikkelsen \& Schlüter 2009). The new 'organic regulation' consists of a 'framework regulation', complemented by 'implementation rules' and guidelines (EC, 2007). For plant protection, the implementation rule $889 / 2008$ is relevant (EC, 2008). The regulation and authorization of plant protection products in organic farming is recently explained by Speiser and Tamm (2011). The authorization in the EU of new plant protection products has started by requests which are submitted by an EU Member State but not by manufacturers to the Commission. Recently, the Commission has set up an 'expert group for technical advice on organic production' responsible for authorization (EC, 2009). Once an active substance is authorized for use, it is up to the certification authority to determine under which conditions commercial products may be used. Although organic farming is governed by one regulation throughout the EU, the practices of plant protection differ significantly from one country to another. This is due to a complex interaction between organic legislation, national private standards, general pesticide legislation, and commercial activities with respect to plant protection products and regional farming traditions. In the EU organic regulation, plant oils, micro-organisms and pheromones are authorized in a generic way. New substances belonging to one of these three groups can be used in organic farming without any further authorization procedure, if they are allowed for use in general agriculture in the EU. Commercial organic production of any crop is only possible if materials or methods are available to regulate the key pests and diseases. New developments require progress in the range of authorized pesticides due to the farm sizes become larger and farms tend to specialize in a decreasing number of crops, consumers requirements with respect to external quality are continuously important, economical conditions like open market, strong demand for high quality food, seed-borne diseases are likely to gain importance in the future because the not allowed use of synthetic fungicides (Tamm, 2000). Actual statuses of three most widespread botanical insecticides in conventional and organic agriculture are presented 
in Table 4. Rotenone is one of controversial substances, its use should be reduced in organic farming and main reasons are explained in the next sections.

\begin{tabular}{|l|l|l|l|l|l|}
\hline $\begin{array}{l}\text { Active } \\
\text { substances }\end{array}$ & Category & $\begin{array}{l}\text { Annex I } \\
\text { (Dir 91/414/EEC) }\end{array}$ & $\begin{array}{l}\text { Regulation } \\
\text { (EC) }\end{array}$ & $\begin{array}{l}\text { MRL } \\
\mathbf{m g} / \mathbf{k g}\end{array}$ & $\begin{array}{l}\text { Organic } \\
\text { Farming } \\
\text { (889/2009) }\end{array}$ \\
\hline Pyrethrins & Insecticide & IN & $2008 / 127$ & $0.05-1$ & IN \\
\hline Rotenone & Insecticide & OUT & $2008 / 317$ & $\begin{array}{l}0.01- \\
0.02\end{array}$ & IN \\
\hline Azadiracthin & Insecticide & IN & $\begin{array}{l}\text { SCoFCAH } \\
\text { Mar 2011 }\end{array}$ & $0.01-1$ & IN \\
\hline
\end{tabular}

Table 4. Actual status of Pyrethrins, Rotenone and Azaditacthin under Dir.91/414/EEC and Organic farming regulation: IN: Included or authorized; OUT: Not included; MRL maximum residue level (EC No 396/2005)

\subsection{An actual case of rotenone}

A very well known group of natural products occurring in the Leguminosae family are rotenoids and their most famous member is Rotenone. Rotenone is extracted from Leguminosae species such as Derris elliptica, Tephrosia vogelli and Lonchocharpus nicou (Copping, 1998). A strain of endophytic Pencillium sp., isolated from the fresh roots of Derris elliptica Benth, might produce rotenone or its analogues and be active against aphids $(\mathrm{Hu}$, 2005). The molecule is named after Roten, who was the first researcher to study this pesticide in Japan at the beginning of the past century. Among 29 rotenoids isolated from cubé resin, obtained from the roots of Lonchocarpus utilis and urucu from Peru, major components are: rotenone $(44.0 \%, \mathrm{w} / \mathrm{w})$, deguelin $(22.0 \%, \mathrm{w} / \mathrm{w})$, rotenolone $(12 \mathrm{a},-$ hydroxyrotenone) $(6.7 \%, \mathrm{w} / \mathrm{w})$, and tephrosin (12a,-hydroxydeguelin) $(4.3 \%, \mathrm{w} / \mathrm{w})$. Additional rotenoids have been isolated and identified but they were likely ascribed to decomposition products generated with the resin processing (Fang \& Casida, 1999). A marked insecticide activity is reported for the main rotenoids (Yenesew, 2003), even though rotenone and deguelin show a similar activity much stronger than their derivatives (Fang \& Casida, 1999).

\subsubsection{Rotenone as biopesticide and mode of action}

Rotenone has a long history of use as a toxin for insects and other arthropods, as well as for fish (Ray, 1991). Rotenone shows a pyrethrin-like behaviour but with a stronger action and a higher persistence (Crombie, 1999). It owes part of its efficacy to its rapid neurotoxic action against insects, named "knock down effect"; and it is used to control aphids, suckers, thrips and other insects on fruit and vegetables (Tomlin, 2000). Rotenone increased the insect's mortality and negatively affected its reproduction (Guadan et al., 2000). Despite rotenone being used for many years as a botanical insecticide (Whitehead \& Bowers, 1983), there are only a few papers about the feeding deterrent activity of rotenone and its derivatives (Bentley et al., 1987; Nawrot et al., 1989). There appear to be differences in the sensitivity of various Lepidoptera species to this compound (Dowd, 1988; Valles \& Capinera, 1993). When ingested, rotenone tended to reduce the amount of food absorbed by the larvae, as well as their ability to convert the absorbed food to biomass (Wheeler et al., 2001). Slow action of rotenone as a stomach or contact poison is known (Fukami \& Nakajima, 1971). Rotenone is 
highly toxic to fish, with 96-h LC50 values of 23 and $2.6 \mathrm{ng} / \mathrm{g}$ to rainbow trout and channel catfish, respectively (Kidd \& James, 1991). It has been used by native tribes as a fish poison to obtain food and more recently in fisheries management to achieve the desired balance of species, e.g., the treatment of Lake Davis in California (California Department of Fish and Game, 1997) as well as the treatment of rivers and river systems in the last 5-10 years in Norway to exterminate the parasite Gyrodactylus salaries of North Atlantic salmon by killing the host (Anonymous, 2002). The application of rotenone to fresh waters can also cause significant declines in zooplankton and certain benthic fauna; however, some invertebrates would normally be expected to recover in a few months (Blakely et al., 2005; Melaas et al., 2001), although the recovery rates are largely dependent upon each taxon's recolonisation ability. Rotenone is toxic to bees when used together with pyrethrin (Kidd \& James, 1991) but alone is used to control the mite Varros jacobsoni which affects colonies of the honey bees (Jimenes et al., 2000; Martel and Zeggane, 2002). There are several studies that reported the persistence of rotenone on food crops after treatment. The half-life of rotenone on olives has found to be 4 days, while at harvest the residue levels were above the tolerance limit with residues in the oil being higher than those on olives by a factor of 2.4-4.8(Cabras et al., 2002). Rotenone was detected at concentration of $0.11 \mathrm{mg} / \mathrm{kg}$ in honeys (Jimènes et al., 2000). Due to the mentioned evidences and the facts reported in the next paragraphs (2.3.2. and 2.3.3) Rotenone is not included in the Annex I of the European Directive 91/414/EC, as well it is provided with a default maximum residue level (MRL) of $0.01 \mathrm{mg} / \mathrm{kg}$ (Table 4). Because of its natural origin, the use of rotenone as an insecticide has been allowed in the last two decades in organic crop production. Rotenone is used in European organic agriculture nowadays, with a strong restriction regarding its environmental hazards. The use of rotenone is partially restricted in Austria, Italy, Spain, Switzerland, and the United Kingdom, but not in Denmark, Netherlands, Portugal, and Slovenia. In the United Kingdom, few private standard-setting organizations allow its use after preliminary permission, while others never permit its use (Speiser \& Schid, 2003). In Italy the use of rotenone formulations is allowed until 30 April 2011 only on apples, peaches, pears and cherries.

\subsubsection{Parkinson Disease (PD) and cancer chemopreventive effect of rotenone}

Rotenone exposure cause neurotoxic effects that may suggest its possible role in the development of a PD-like syndrome in animals. Rotenone treatment causes lesions to the nigrostriatal system that are consistent with PD, via production of Reactive Oxygen Species due to inhibition of mitochondrial Complex I (Sherer et al., 2003 a) and glial activation (Sherer et al., $2003 \mathrm{~b}$ ). Although the effects of Rotenone on the brain were first tested over 20 years ago, the model received the most attention when reproduced with a chronic mode of iintravenous delivery (Betarbet et al., 2000). There are several issues that have disadvantaged acceptance of the chronic Rotenone model, the most important is variability. Different modes of administration have been explored and in specific the intractranial (Saravanan et al., 2005), intravenous (Milusheva et al., 2005), subcutaneous (Caboni et al., 2004), intraperitoneal (Cannon et al., 2009) and more recently, others such as oral (Inden et al., 2007) and intranasal (Rojo et al., 2007) delivery that are arguably more realistic with regard to potential entry sites for toxin exposure in human PD. Unfortunately, these novel routes have only been reported in single studies with limited pathological analysis. The Rotenone model is evidence demonstrating marked systemic non-specificity is nonspecificity within the central nervous system does not reproduce the pathology of PD but 
rather induces a pattern of pathological changes. In addition, there remain critical issues regarding the translatability of the model: does the Rotenone model truly recapitulate human PD? These data can be of help for understanding the role of pesticide exposure in human PD development. On the other hand farmers exposed for days or weeks during several years to much lower doses than those used in experimental studies. Therefore, a conclusion on the role of pesticide exposure on the increased risk of developing PD cannot be drawn (Moretto \& Colosio, 2011). Future studies should include histopathological analyses of other systems and perhaps attempt to evaluate the model from a different angle, shedding light onto the potential value of these "nonspecific" effects in reproducing other aspects of PD pathology (Cicchetti et al., 2009). Rotenone is known not only as a toxicant but also as candidate anticancer agents (Fang et al., 1997, Rowlands \& Casida, 1998). Rotenone induces mitotic catastrophe, mitotic slippage, cell death and cellular senescence in cancer cells (Gonçalves et al., 2011).

\subsubsection{Chemical and photochemical fate of rotenone in the soils in relation to the soil components}

Both the accumulation of pesticides in the soil and their dispersion in the environment depend chiefly on the characteristics and overall functioning of the ecosystem. Soil represents a major sink for organic xenobiotic contaminants in the environment. It is necessary to establish the fate of the parent compound and its degradation products in the soil in order to completely evaluate the environmental hazard of rotenone. In order to fulfill the lack of information regarding the rotenone fate in the soil several studies have been carried out by the authors. In experiments carried out to study photodegradation of rotenone in soils under environmental conditions, the observed overall degradation of rotenone is not only determined by photolysis itself but also as a function of soil characteristics, and it appears to be reduced and affected by several other physical-chemical mechanisms (Cavoski et al., 2007). Results indicate that the photochemical behavior of rotenone is significantly affected by the soil physicochemical characteristics. The three soils used in the experiment show significantly different net losses due to the sunlight exposure, the photolysis rate ranging from 0.12 to $0.18 \mathrm{~min}^{-1}$. However, the contribution of the photochemical processes to the global consumption rate is higher in soils richer in organic matter than that in sandy soil. The photodegradation of rotenone on soil surfaces principally produces an oxidized metabolite, rotenolone (12a $\alpha$-hydroxyrotenone) (Fig. 2). The photolysis reaction proceeds better fit two compartment or multiple compartment model pathways. A fast initial decrease during the first 5 hours of rotenone irradiation is followed by a much slower decline (lasting more than 10 hours), which clearly indicates the rather complex chemical process of rotenone photodegradation on soil surfaces. In the initial decrease, the degradation in soils of rotenone is mainly effected by direct sunlight irradiation and proceeds at a high rate; then, following rotenone adsorption on soil particle surfaces, it appears to reduced and be effected by several other physical-chemical mechanisms. On the other hand in the standardized laboratory experiments regarding rotenone degradation in soil we proofed that chemical degradation process markedly more complex than its photodegradation on soil surfaces and the contribution of chemical processes to the global degradation rate is higher in sandy soil than in soils richer in organic matter (Fig. 2). The half lifes of rotenone and 12a $\alpha$-hydroxyrotenone (major metabolite), were 8 and 5 days, 23 and 56 days at $20^{\circ} \mathrm{C}$, respectively. However, at $10{ }^{\circ} \mathrm{C}$ a tendency for slower degradation of rotenone and 12a $\alpha$-hydroxyrotenone was observed ( 25 and 118 days 
and 21 and 35 days, respectively). Results show that the degradation rates of both rotenone and $12 \mathrm{a} \beta$-hydroxyrotenone were greatly affected by temperature changes. Rotenone degradation phenomena are described by a bi-phasic equation, while metabolites degradation kinetics is described by a first order equation. Rotenolone is more persistent then rotenone in the soil. Chemical degradation was strongly affected by soil adsorption properties, soil temperature and rotenone characteristics. Adsorption processes affect its degradation in the soil mainly by modifying its chemical bioavailability and activity. Variability in degradation rate has provided evidence for possible field-to-field variation in the degradation rates of rotenone in the environment. A greater understanding of the factors that influence degradation rates is required to support obtained results.

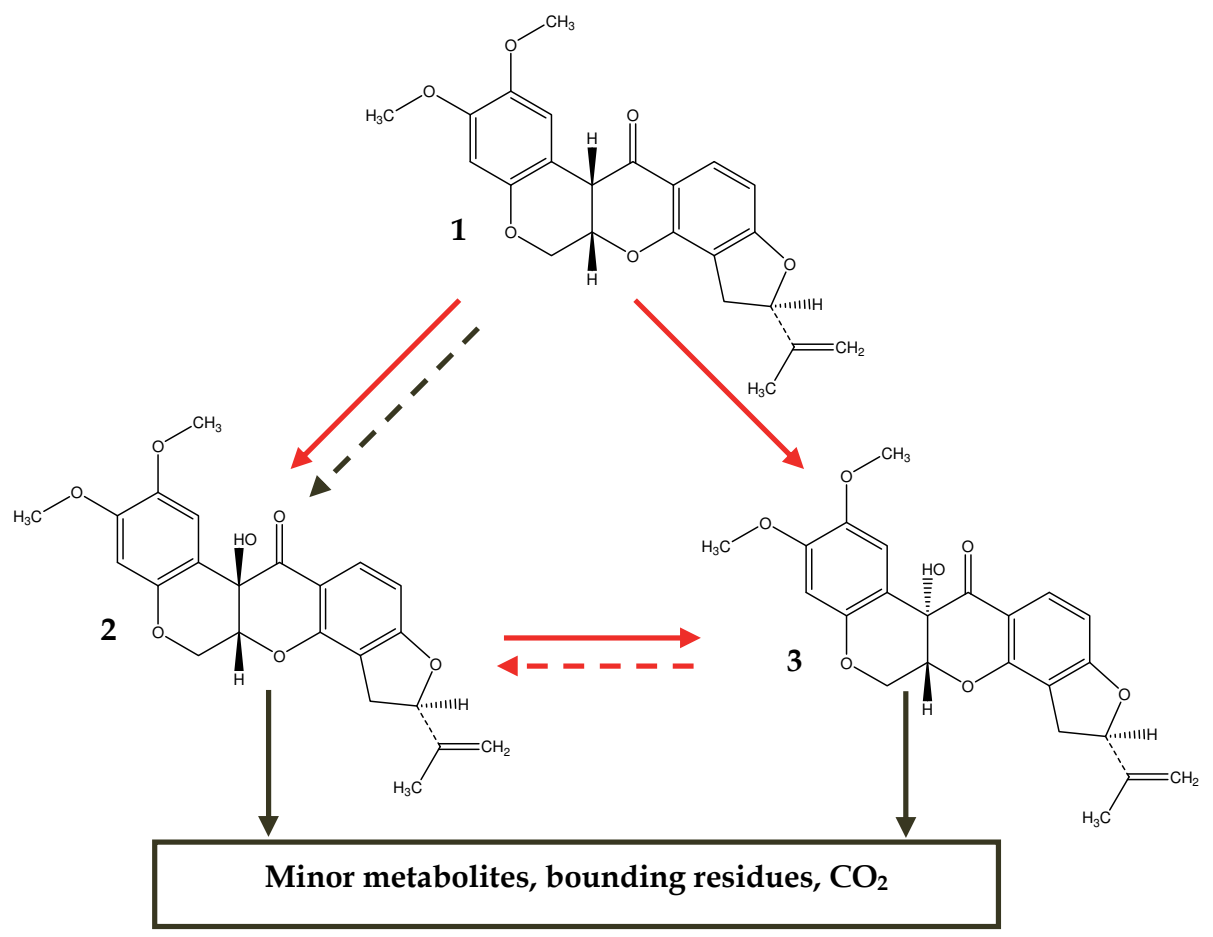

Fig. 2. Chemical (_- $)$ and Photochemical (--------) pathway of rotenone in soil. 1Rotenone, 2-12a $\beta$ - hydroxyrotenone and 3- 12a $\alpha$ - hydroxyrotenone

The principal photochemical reaction of rotenone on soil surfaces is photoxidation (Fig. 2), producing an oxidized metabolite - rotenolone (12aß-hydroxyrotenone). The photodegradation kinetic can be explained by a multiple compartment model. A fast initial decrease during the first few hours of rotenone irradiation is followed by a much slower decline. In the initial decrease, the degradation of rotenone in soils is mainly affected by direct sunlight irradiation and proceeds at high rate (probably initiated by its photosensitizer properties); then, following rotenone adsorption on soil particle surfaces, it is reduced and affected by several other physico-chemical mechanisms. Chemical transformation of rotenone in a soil (Fig. 2), such as hydrolysis and oxidation, are important 
phenomena but, however, isomerization has also been observed in standard laboratory studies. Main metabolites were 12a $\beta$-hydroxyrotenone and its isomer 12a $\alpha$ hydroxyrotenone, indicating the rather complex chemical process of rotenone degradation in soil with respect to its photodegradation on soil surfaces. In order to understand the role of organic fraction in the soil on rotenone degradation we investigated mechanism by which rotenone binds to the humic acids relative to their origin and properties by means of spectroscopic studies. Results demonstrated that the rotenone adsorption onto humic acids can be achieved by different mechanisms, as a function of the compositional, structural, and functional properties humic material have been obtained (Fig. 3.). The most important

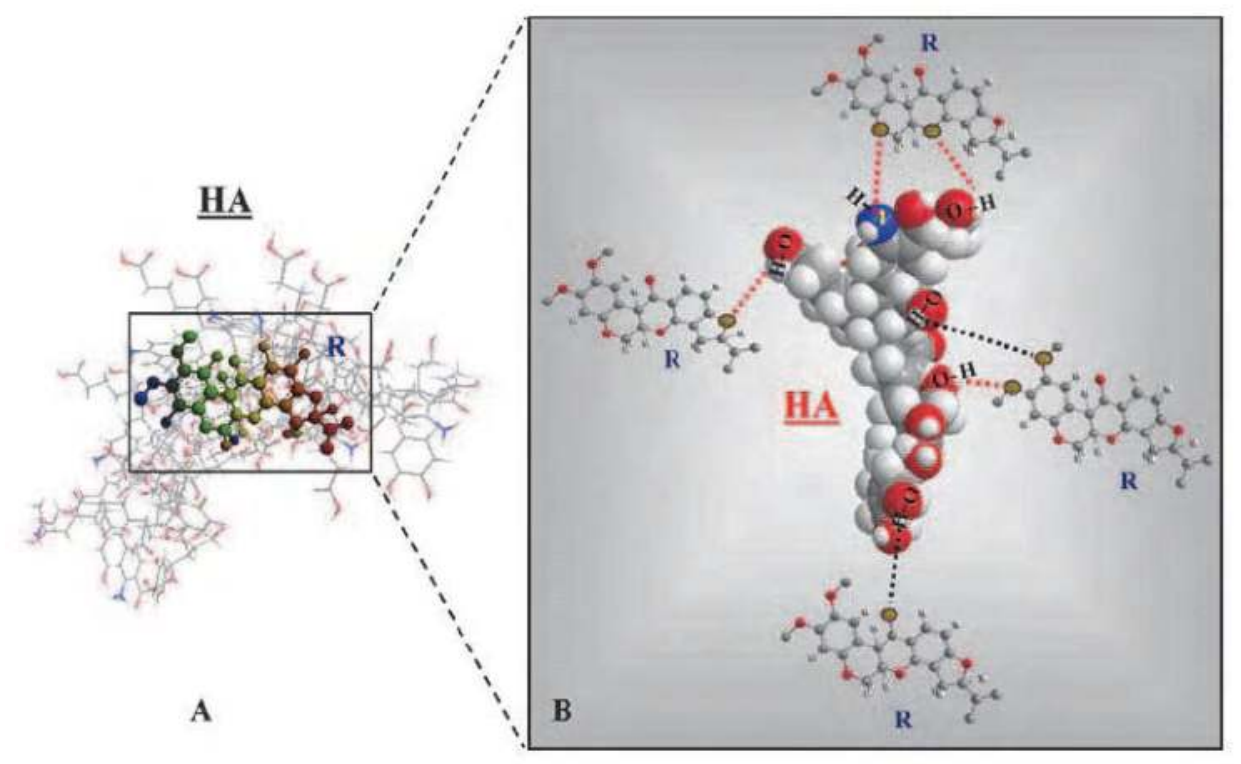

Fig. 3. Schematic representation of binding mechanisms possibly occurring between various structural units of humic acid (HA) macromolecules and rotenone (R): A- hydrophobic and B- hydrogen bonds

parameters determining a prevalence of a specific mechanism with respect to others are the oxygenated group's content and the aromatic degree of humic acids. These characteristics result in a different chemical reactivity and a residual adsorbing capacity of the humic acids toward the non-polar rotenone molecule. The humic acids characterized by a greater aromaticity degree and lower polarity, featured by a mixed aromatic/aliphatic character, rotenone resulted preferentially adsorbed onto these humic acids by hydrophobic interaction, whereas onto mainly aliphatic and acidic humic acids the hydrogen bonds resulted predominant. The most important parameters determining a prevalence of a specific mechanism with respect to others are the oxygenated groups content and the aromatic degree. These characteristics result in a different chemical reactivity and a residual adsorbing capacity of the humic acids toward the non-polar rotenone molecule. The FT-IR spectroscopy data indicated weak interaction between rotenone and humic acids, involving mainly hydrogen bonding, and possibly also hydrophobic forces. Fluorescence 
spectroscopies data appear very informative and clear, suggesting that rotenone, preferentially binds to humic acids by hydrophobic interaction (Cavoski et al., 2009). Results provide additional insights about transformation phenomena and metabolite production of rotenone in the environment, describing more clearly the degradation performances as a function of various physico-chemical parameters.

\subsection{Pyrethrins and Azadirachtin actual status}

Neem oil extracted from the seeds of neem tree (Azadirachta indica) has been known to contain many bioactive compounds. These compounds are triterpenoids of the class of limonoids. Major limonoids reported in literatures are azadirachtin (azadirachtin A), salanin, nimbin, 3-tigloylazadirachtol (azadirachtin B), and 1-tigloyl-3-acetyl-11hydroxymeliacarpin (azadirachtin D) (Govindachari et al., 1996, 2000; Isman, 2006, 1990; Kumar, 1996; Mordue \& Blackwell, 1993; Morgan, 2009; Mitchell, 1997). These compounds are responsible for diverse activities such as insect antifeedant, insect growth disrupting, insecticidal, nematicidal, fungicidal, bactericidal, etc. (Kavathekar, 2003). Many other compounds are present in smaller quantities in neem seeds (Hallur et al., 2002; Kumar et al. 1996a, 1996b; Ragasa et al, 1997; Siddiqui et al., 1986). Therefore, most products from neem oil are usually represented by their azadirachtin content although they also contain other compounds (Isman, 2006). Azadirachtin content in crude neem oils varies from negligible to more than 4000 mg/kg (Govindachari et al., 1996; Kumar et al., 1997). Limonoids are soluble in polar and mid-polar solvents and slightly soluble in water. Separation of azadirachtin and other limonoids from neem seed or oil can be carried out by using various methods. Still there are studies regarding the recovery of azadirachtin from defatted neem kernels in order to optimize the extraction processes. The hexane induced precipitation is a potential preconcentration step in the separation of azadirachtin and other limonoids from neem oils where azadirachtin purities in the powders is $14.85 \%$ and $7.34 \%$, respectively, which represented more than 180-fold enrichment from initial content in neem oils of $0.1 \%$ (Melwita \& Ju, 2010). Sunlight photodegradation is the main factor influencing the rate of it decomposition after tomato greenhouse treatment. Under field conditions azadirachtin and other neem constituents, e.g., salannin, nimbin, deacetylnimbin, and deacetylsalannin, are not persistent. Three days post field application at the dose five times higher than recommended by the manufacturer, residues of azadirachtin $\mathrm{A}$ and $\mathrm{B}$ were 0.03 and 0.01 $\mathrm{mg} / \mathrm{kg}$, respectively, while residues of salannin and nimbin were not detectable (Caboni et al., 2006; 2009).

Azadirachtin is one of the 295 substances of the fourth stage of the review program; the peer review process was subsequently terminated following the applicants' decision to withdraw support for the inclusion of azadirachtin in Annex I of Council Directive 91/414/EC by Decision 2008/941. The reasons for this decision were related to incomplete data regarding metabolism in plants, animals and soil by using radio labeled isotope and toxicologicalecotoxicological data for all limonoids present in extract and formulations were required. Approximately 30 additional studies were performed in order to fulfill missing data. IFOM has been sent different letter to EFSA (European Food Safety Association) (letter_IFOAMEU_COM_lime_sulphur_azadirachtin_EFSA_16.11.2010) for its inclusion, explaining the importance of azadirachtin for the control one of the most dangerous key pests in organic fruit production the rosy apple aphid (Dysaphis plantaginea), and its role in resistance management in organic farming for several pests, e.g. the Colorado potato beetle (Leptinotarsa decemlineata). At the time when this chapter was written, azadirachtin was 
included in Annex I (SCoFCAH Mar 2011 according to Reg. 33/2008) based on EFSA review (EFSA, 2011) (Table 4).

Pyrethrum is a powder obtained by crushing dried flowers of daisies belonging to the family of Asteraceae such as Chrysanthemum. spp., Pyrethrum. spp., and Tanacetum. spp. Pyrethrum is a mixture of six esters, pyrethrins I and II, (the most abundant), cinerin I and II, and jasmoline I and II. Sunlight photodegradation is the main factor influencing the rate of it disappearance after the application at ten times the dose recommended by the manufacturer disappearance time was 2.3 days (Angioni et al., 2005). Pyrethrum was the only botanical included in the Annex I after the fourth stage of re-evaluation. Cultivation is the most suitable option as a large continuous supply of raw material is needed for commercial production. At the moment Kenya produce $70 \%$ of pyrethrin world production. In Europe, France (AgriPlantes) has been developed the project for pyrethrin production in order to reduction of fluctuation of price and guaranty of formulation quality by controlled harvesting conditions (Isman, 2008). In Mediterranean basin there are various soils and climatic conditions appropriate for pyrethrin growth but high labor cost is limited factor. In the formulation pyrethrum is mixed with piperonyl butoxide, a synergist used for a wide variety of insecticides formulation, in order to increase the effectiveness. At the present time there is strong restriction regarding the use of piperonyl butoxide in the formulations for organic farming. Synthetic piperonyl butoxide is considered a non-allowed "inert ingredient" and pyrethrum products may be synergized only with piperonyl butoxide from a natural source, such as oil of sassafras according to Soil Association. Imported products treated with synthetic piperonyl butoxide can be certified only as "equivalent".

\section{Conclusion}

The researchers suggest that certain organic management practices are not necessarily more environmentally sustainable than conventional systems. An integrated pest management approach might be more suitable, as such a system is flexible enough to include whichever practices have the smallest environmental impact (Bahlail et al., 2010). In order to optimize environmental sustainability, natural pesticides must be evaluated for their environmental impact in the context of an integrated approach, and that policy decisions must be based on empirical data and objective risk-benefit analysis, not arbitrary classifications. Life cycle toxicity assessment of pesticides used in integrated and organic production showed that organic production represents the least toxic pest-control method. The authors concluded that a careful selection of pesticides used in the production can minimize human toxicity impacts by two orders of magnitude while freshwater ecotoxic impacts can be reduced by up to seven orders of magnitude (Juraske and Sanjuán, 2011). The new categories of low-risk active substances and basic substances under EU regulations (1107/2009) seem to make legal regulation of low-risk active substances more easily and faster but only after submission of a heavy dossier and the complex evaluation process. In addition, basic substance approach appears to be without significant interest for the industrial production of natural pesticides. Directive 2009/128 on sustainable use creates promising opportunities for non-chemical methods and organic farming which must be taken in consideration in National Action Plans. The bottleneck of new plant protection products legal regulation is a time and cost consuming. Possibly it is time to refocus the attention of the research community toward the development and application of known botanicals rather than screen more plants and isolate further novel bioactive substances by developing new technology in botanicals formulation. 


\section{Acknowledgment}

The authors like to express their special thanks to Dr Nikoletta Ntalli (Aristotle University of Thessaloniki) for reviewing the chapter and useful suggestions.

\section{References}

Angioni, A., Dedola, F., Minelli, E.V., Barra, A., Cabras, P., Caboni, P. (2005). Residues and half-life times of pyrethrins on peaches after field treatments. J. Agric. Food Chem.,53 (10):4059-63

Anonymous (2002). Tiltaksplan for arbeidet med bekjempelse av Gyrodactylus salaris i norske laksevassdrag. Direktoratet for naturforvaltning og Statens dyrehelsetilsyn. [Action plan for control and eradication of Gyrodactylus salaris in Norwegian salmon rivers. Norwegian Directorate for Nature Management and Norwegian Animal Health Authority] September 2002, p. 19.

Bahlai, C.A., Xue, Y., McCreary, C.M., Schaafsma, A.W., Hallett, R.H. (2010). Choosing Organic Pesticides over Synthetic Pesticides May Not Effectively Mitigate Environmental Risk in Soybeans. PLoS ONE 5(6): e11250

Bentley, M.D., Hassanali, A., Lwande, W., Njoroge, P.E.W., OleSitayo, E.N., Yatagai, M. (1987). Insect antifeedants from Tephrosia elata Deflers. Insect Sci. Its Appl, 8, 85-88.

Bernhard Speiser \& Lucius Tamm (2011) Regulation of Plant Protection in Organic Farming in Regulation of Biological Control Agents, Ehlers, R.U., Part 1, 113-125, DOI: 10.1007/978-90-481-3664-3_4, Springer Science+Business Media B.V. 2011.

Betarbet, R., Sherer, T.B., MacKenzie, G., Garcia-Osuna, M., Panov, A.V., Greenamyre, J.T. (2000). Chronic systemic pesticide exposure reproduces features of Parkinson's disease. Nat Neurosci., 3(12):1301-6

Blakely, T.J., Chadderton, W.L., Harding, J.S., 2005. The effect of rotenone on orchardpond invertebrate communities in the Motueka area, South Island, New Zealand. DOC Research \& Development Series 220. Department of Conservation, Wellington. p. 26.

Caboni, P., Sherer, B.T., Zhang, N., Taylor, G., Na, M.H., Greenamyre, T., Casida, J.E., 2004. Rotenone, deguelin, their metabolites, and the rat model of Parkinson's disease. Chem. Res. Toxicol., 17, 1540-1548

Caboni, P., Sarais, G., Angioni, A., Lai, F., Dedola, F. \& Cabras, P. (2009). Fate of azadirachtin $\mathrm{A}$ and related azadirachtoids on tomatoes after greenhouse treatment. J. Environ. Sci. Health, Part B: Pestic., Food Contam., Agric. Wastes, 44(6, August): 598-605.

Caboni, P., Sarais, G., Angioni, A., Garcia, A.J., Lai, F., Dedola, F. \& Cabras, P. (2006). Residues and persistence of neem formulations on strawberry after field treatment. J. Agric. Food Chem., 54: 10026-10032.

Cabras P, Caboni P, Cabras M, Angioni A, Russo M. (2002). Rotenone residues on olives and in olive oil. J. Agric. Food Chem. 50:2576-80. 
California Department of Fish and Game. Lake Davis Northern Pike Eradication Project, January 1997, Final environmental impact; The Resources Agency: Sacramento, CA. 1997.

Cannon, J.R., Tapias, V., Na, H.M., Honick, A.S., Drolet, R.E., Greenamyre, J.T. (2009) A highly reproducible rotenone model of Parkinson's disease. Neurobiol Dis , 34:279290

Cavoski, I., Caboni, P., Sarais, G., Cabras, P., Miano, T (2007). Photodegradation of Rotenone in Soils under Environmental Conditions. J. Agric. Food Chem., 55 (17), 7069-7074.

Cavoski, I., Caboni, P., Sarais, G., Miano, T. (2008). Degradation and Persistence of Rotenone in Soils and Influence of Temperature Variations. J. Agric. Food Chem., 56 (17), 80668073 .

Cavoski, I., D'Orazio, V., Miano, T. (2009). Interactions between rotenone and humic acids by means of FT-IR and fluorescence spectroscopies. Anal Bioanal Chem. 395(4):114558.

Cicchetti, F., Drouin-Ouellet, J., Gross, R.E. (2009). Environmental toxins and Parkinson's disease: what have we learned from pesticide-induced animal models? TIPS;30: 475-83.

Codex Alimentarius Commission (1999) Guidelines for the production, processing, labelling and marketing of organically produced foods. GL 32-1999. Rev 4 2007. Rome

COM (2004) European Action Plan for Organic Food and Farming. document COM (2004) 415 final. http://ec.europa.eu/agriculture/organic/eu-policy/actin-plan_en (accessed on 17 March 2011)

Copping, L.G., 1998. The Biopesticide Manual; BCPC: Farnham, U.K., 1998, pp 35-36.

Copping L.G. \& Menn J.J. (2000). Biopesticides: a review of their action, applications and efficacy. Pest management science, 56: 651-676.

Council Regulation (EC) No 834/2007 of 28 June 2007 on organic production and labelling of organic products and repealing Regulation (EEC) No 2092/91. Official Journal of the European Union L 189/1 (28.7.2007).

Crombie, L., (1999). Natural product chemistry and its part in the defence against insects and fungi in agriculture. Pestic. Sci. 55, 761-774.

Department for Environment, Food and Rural Affairs (DEFRA). (2002). The strategy for sustainable food and farming, facing the future. London: DEFRA.

Dowd, P.F. (1988). Toxicological and biochemical interactions of the fungal metabolites fusaric acid and kojic acid with xenobiotics in Heliothis zea (F.) and Spodoptera frugiperda (J.E. Smith). Pesticide Biochemistry and Physiology, 32, 123-134.

Dubey, N.K., Kumar, A., Singh P. \& Shukla R. (2009). Exploitation of Natural Compounds in Eco-Friendly Management of Plant Pests. U. Gisi et al. (eds.), Recent Developments in Management of Plant Diseases, Plant Pathology in the 21st Century 1, DOI 10.1007/978-1-4020-8804-9_14, Springer Science+Business Media B.V. 2009, 181-198. (http:// www.oecd.org/dataoecd/6/20/28725175.pdf)

EC (2001) Commission of the European Communities, Commission Directive 2001/36/EC of 16 May 2001 amending Council Directive 91/414/EEC concerning the placing of 
plant protection products on the market. Off J Eur Union. Luxembourg (www.eurolex.europa.eu)

EC (1991) Council regulation No 2092/91 of June 241991 on organic production of agricultural products and indications referring thereto on agricultural products and foodstuffs. Off J Eur Commun L 198:22/07, 1991:0001-0015

EC (2007) Council regulation (EC) No 834/2007 of 28 June 2007 on organic production and labelling of organic products and repealing Regulation (EEC) No 2092/91. Off J Eur Commun L 189/1 (20.7.2007):1-23

EC (2008) Commission regulation (EC) No 889/2008 of 5 September 2008, laying down detailed rules for the implementation of Council Regulation (EC) No 834/2007 on organic production and labelling of organic products with regard to organic production, labelling and control. Off J Eur Commun L 250/1 (18.9.2008):1-84

EC (2009) Commission Decision of 3 June 2009 establishing the expert group for technical advice on organic production (2009/427/EC). Off J Eur Union L139:29-31

Ecophyto2018, Selected items from the French pesticide reduction plan http:/ /agriculture.gouv.fr/IMG/pdf/ecophyto2018-avril09.pdf

Ehlers, R.U. (2009) REBECA - EU-Policy Support Action to Review Regulation of Biological Control Agents. Recent Developments in Management of Plant Diseases, Plant Pathology in the 21st Century 1, Gisi U., Gullino M.L. \& Chet I. DOI 10.1007/978-1-4020-8804-9_14, Springer Science+Business Media B.V. 2009, 147161.

European and Mediterranean Plant Protection Organization, EPPO (1998). “Guidelines for the Safety and Efficacy of Biological Control: First Introduction of Exotic Biological Control Agents for Research Under Contained Conditions"

European Food Safety Authority; Conclusion on the peer review of the pesticide risk assessment of the active substance azadirachtin. EFSA Journal 2011;9(3):1858. [76 pp.]

doi:10.2903/j.efsa.2011.1858. Available online: www.efsa.europa.eu/efsajournal.htm.

Fang, N., Rowlands, J.C., Casida, J.E., (1997). Anomaluos structure- activity relationships of 13-homo-13-oxarotenoids and 13-homo-13-oxadehydrorotenoids. Chem. Res. Toxicol., 10, 853-858.

Fang, N. \& Casida, J.E., (1998). Anticancer action of cube' insecticide: Correlation for rotenoid constituents between inhibition of NADH: ubiquinone oxidoreductase and induced ornithine decarboxylase activities (rotenone). Proc. Natl. Acad. Sci. USA, 95, 3380-3384.

FiBL \& IFOAM (2010): Results of the Global Survey on Organic Agriculture 2010. The Organic World Homepage, FiBL, Frick, www.organicworld.net/statisticsworld.html

Food and Agriculture Organization of the United Nations, FAO (1996). International Standards for Phytosanitary Measures: Code of Conduct for the Import and Release of Exotic Biological Control Agents. February

Fukami, H. \& Nakajima, M. (1971). Rotenone and the rotenoids. In Naturally Occurring Insecticides. Jacobson, M., Croeby, D. G., Dekker, New York. 
Gafsi, M., Legagneux, B., Nguyen, G., \& Robin, P. (2006). Towards sustainable farming systems: effectiveness and deficiency of the French procedure of sustainable agriculture. Agricultural Systems, 90, 226-242.

Gonçalves, A. P. , Máximo, V., Lima, J., Singh, K.K., Soares, P., Videira, A. (2011). Involvement of p53 in cell death following cell cycle arrest and mitotic catastrophe induced by rotenone, Biochimica et Biophysica Acta 1813; 492-49.

Govindachari, T.R., Suresh, G. Gopalakrishnan, G., Wesley S.D. (2000), Insect antifeedant and growth-regulating activities of neem seed oil: the role of major tetranortriterpenoids, J. Appl. Entomol. 124; 287-291.

Govindachari, T.R. , Narasimhan, N.S., Suresh, G., Partho, P.D., Gopalakrishnan, G. (1996) Insect antifeedant and growth-regulating activities of salannin and other Cseco limonoids from neem oil in relation to azadirachtin, J. Chem. Ecol. 22 14531461.

Govindachari, T.R., Sandhya, G., Ganeshraj, S.R. (1991). Isolation of novel azadirachtinsH and I by high-performance liquid chromatography, Chromatographia 31303-305.

Guadan, A., Gutierrez, C., de la Pena, E., Cortes, D., Gonzalez-Coloma, A., (2000). Insecticidal and Mutagenic Evaluation of Two Annonaceous Acetogenins. J. Nat. Prod., 63, 773-776.

Hallur, G., Sivramakrishnan, A., Bhat, S.V. (2002), Three new tetranortriterpenoids from neem seed oil, J. Nat. Prod. 65 1177-1179.

Hu, M.Y., (2005). Insecticidal activities of secondary metabolites of endophytic Pencillium sp. in Derris elliptica Benth, J. Appl. Entomol., 129 (8), 413-417.

Inden, M, Kitamura, Y., Takeuchi, H., Yanagida, T., Takata, K., Kobayashi, Y., Taniguchi, T., Yoshimoto, K., Kaneko, M., Okuma, Y., Taira, T., Ariga, H., Shimohama, S. (2007). Neurodegeneration of mouse nigrostriatal dopaminergic system induced by repeated oral administration of rotenone is prevented by 4-phenylbutyrate, a chemical chaperone. J Neurochem 101, 1491-1504

Isman, M.B., (2006) Botanical insecticides, deterrents, and repellents in modern agriculture and an increasingly regulated world, Annu. Rev. Entomol. 51 45-66.

Isman, M.B., Koul, O., Luczynski, A., Kaminski, J. (1990), Insecticidal and antifeedant bioactivities of neem oils and their relationship to azadirachtin content, J. Agric. Food Chem. 38 1406-1411.

Isman, M.B. (2006). Botanical insecticides, deterrents and repellents in modern agriculture and an increasingly regulated world. Annual review of entomology, 51: 45-66.

Isman M.B. \& Machial C.M. (2006). Pesticides based on plant essential oils: from traditional practice to commercialization. In: Rai M. and Carpinella M.C. (eds). Advances in phytomedicine, 3. Naturally occurring bioactive compounds. Elsevier, New York, pp. 2944. 
Jimenez, J.J., Bernal, J.L., del Nozal, M.J., Novo, M., Higes, M., Llorente, J., (2000). Determination of rotenone residues in raw honey by solid-phase extraction and high-performance liquid chromatography. J. Chromatogr. A, 871, 67-73.

Juraske, R. \& Sanjuán, N (2011). Life cycle toxicity assessment of pesticides used in integrated and organic production of oranges in the Comunidad Valenciana, Spain. Chemosphere 82; 956-962.

Kavathekar, K.Y. (2003) ,Neem in India, NISCAIR, New Delhi, pp. 21-23.

Kidd, H. \& James, D.R. (1991) Agrochemicals Handbook; The Royal Society of Chemistry: Cambridge, U.K.

Kumar J., Parmar B.S., (1996a) Physicochemical and chemical variation in neem oils and some bioactivity leads against Spodoptera litura F., J. Agric. Food Chem. 44 21372143.

Kumar, C.S.S.R., Srinivas M., Yakkundi, S. (1996b) Limonoids from the seeds of Azadirachta indica, Phytochemistry 43 451-455.

Kutchan T. \& Dixon R.A. (2005). Secondary metabolism: nature, chemical reservoir under deconvolution. Current opinion in plant biology, 8: 227_229

Lampkin N (1990) Organic farming. Farming Press, Ypswich

Martel, A.C. \& Zeggane, S. (2002). Determination of acaricides in honey by high-performnce liquid chromatography with photodiode array detection. J. Chromag. A, 954, 173180.

Melaas, C.L., Zimmer, K.D., Butler, M.G., Hanson, M.A. (2001). Effects of rotenone on aquatic invertebrate communities in prairie wetlands. Hydrobiologia, 459, 177186.

Melwita, E. \& Ju, Y.H. (2010). Separation of azadirachtin and other limonoids from crude neem oil via solvent precipitation. Separation and Purification Technology 74, 219-224.

Mikkelsen, C. \& Schlüter, M. (2009) The new EU regulation for organic food and farming: (EC) No 834/2007. IFOAM, Brussels

Milusheva, E., Baranyi, M., Kittel, A., Sperlagh, B., Vizi, E.S., (2005). Increased sensitivity of striatal dopamine release to $\mathrm{H}_{2} \mathrm{O}_{2}$ upon chronic rotenone treatment. Free Radic Biol Med 39, 133-142

Mitchell, M.J., Smith, S.L. Johnson, S., Morgan, E.D. (1997). Effects of the neem tree compounds azadirachtin, salannin, nimbin, and 6-desacetylnimbin on ecdysone 20monooxygenase activity, Arch. Insect Biochem. 35 199-209.

Mordue J. \& Blackwell, A. (1993) Azadirachtin: an update, J. Insect Physiol. 39, 903-924.

Moretto, A. \& Colosio, C. (2011). Biochemical and toxicological evidence of neurological effects of pesticides: The example of Parkinson's disease. Neurotoxic 1226 ; $1-9$.

Morgan, E.D. (2009), Azadirachtin, a scientific gold mine. Bioorgan. Med. Chem. 17, 40964105.

Nawrot, J., Harmatha, J., Kostova, I., Ognyanov, I. (1989). Antifeeding activity of rotenone and some derivatives towards selected insect storage pests. Biochem. Syst. Ecol., 17, $55-57$. 
Ncube, N.S., Afolayan, A.J., Okoh, A.I. (2008). Assessment techniques of antimicrobial properties of natural compounds of plant origin: current methods and future trends. African journal of biotechnology, 7 (12): 1797-1806.

Ntalli N.G. \& Menkissoglu-Spiroudi U. (2011) Pesticides of Botanical Origin: a Promising Tool in Plant Protection in M. Stoytcheva (Ed) Pesticides - Formulations, Effects, Fate, ISBN: 978-953-307-532-7, InTech, 2011

OECD (2001) OECD Guidance for Registration Requirements for Pheromones and Other Semiochemicals Used for Arthropod Pest Control, Series on Pesticides No. 12 (http:/ / www.oecd.org/dataoecd/5/44/31919832.pdf)

OECD (2003) Guidance for Information Requirements for Regulation of Invertebrates as Biological Control Agents (IBCAs), Series on Pesticides No. 21

OECD (2004) OECD Guidance for Industry Data Submissions for Microbial Pest Control Products and their Microbial Pest Control Agents (Dossier Guidance for Microbials), Series on Pesticides No. 23 (http:/ / www.oecd.org/dataoecd/60/6/30919600.pdf)

Ragasa, C.Y.,. Nacpil, Z.D, Natividad, G.M., Tada, M., Coll, J.C., Rideout, J.A., (1997) Tetranortriterpenoids from Azadirachta indica, Phytochemistry 46555-558.

REBECA deliverable 14. Summary of risks and tools to determine risks for botanicals and semiochemicals REBECA Reglation of biological control agents (EC-Project no. SSPE-CT-2005-022709), January 1, 2006 - December 31, 2007 (www.rebeca.com)

Regulation (EC) No 396/2005, of the European Parliament and of the Council of 23 February 2005 on maximum residue levels of pesticides in or on food and feed of plant and animal origin and amending Council Directive 91/414/EEC., Official Journal of the European Union.

Rojo, A.I., Cavada, C., De Sagarra, M.R., Cuadrado, A. (2007). Chronic inhalation of rotenone or paraquat does not induce Parkinson's disease symptoms in mice or rats. Exp Neurol, 208:120-6.

Rowlands, J.C. \& Casida, J.E. (1998). NADH: ubiquinone oxidoreductase inhibitors block induction of ornithine decarboxylase activity in MCF-7 human breast cancer cells. Pharmacol.Toxicol., 83, 214-219.

Sahota, A. (2009). The global market for organic food and drink. In H. Willer, \& L. Kilcher (Eds.), The World of Organic Agriculture, Statistics and Emerging Trends 2009. Bonn, FIBL-IFOAM Report.

Sanco/10472/2003 -rev.5 6.7.2004 Draft working document concerning the data requirements for active substances of plant protection products made from plants or plant extracts

(http:/ / ec.europa.eu/food/plant/protection/evaluation/chem_subst.pdf).

Saravanan, K.S., Sindhu, K.M., Mohanakumar, K.P. (2005) Acute intranigral infusion of rotenone in rats causes progressive biochemical lesions in the striatum similar to Parkinson's disease. Brain Res 1049, 147-155

Sarker, S.D., Latif, Z., Gray, A.I. (2005). Natural product isolation. In: Natural product isolation. 2nd Sarker S.D., Latifi Z. I., Gray A. Humana Methods in biotechnology, 20.Press, Totowa, New Jersey, pp. 1-25. 
Schmidt, H., Haccius, M. (2008) EG-Verordnung “Ökologischer Landbau”. hpslex publishing, Freiburg im Breisgau

Sherer, T.B., Betarbet, R., Testa, C.M., Seo, B.B., Richardson, J.R., Kim, J. (2003a) Mechanism of toxicity in rotenone models of Parkinson's disease. J Neurosci;23:10756-64.

Sherer, T.B., Betarbet, R., Kim, J.H., Greenamyre, J.T. (2003b). Selective microglial activation in the rat rotenone model of Parkinson's disease. Neurosci Lett; 341:87-90.

Siddiqui, S., Faizi, S., Mahmood, T., Siddiqui, B.S. (1986), Two new Insect growth regulator meliacins from Azadirachta indica A. Juss (Meliaceae), J. Chem. Soc. Perkin Trans. 1 1021.

Speiser, B., Schmid, O., Eds. Current evaluation procedure for plant protection products used in organic agriculture. Proceedings of a workshop held in Frick, Switzerland, Sept 2526, 2003; Research Institute of Organic Agriculture FiBL: Frick, Switzerland; Vol 1, pp 1-107 (http://www.organicinputs.org/documents/speiser-schmid-2004inputs.pdf).

Speiser, B., Wyss, E., Maurer, V. (2006).Biological control in organic production: first choice or last option? In: An ecological and societal approach to biological control. Eilenberg, J., Hokkanen, H. Springer, Dordrecht, pp 27-46

Sylvander, B., François, M. (2006) Organic and low input food consumers' concerns and perspectives for developing the organic market in the future. In: Organic Farming and European Rural Development. Andreasen, C., Elsgaard L., Sondergaard- Sorensen L.; Hansen G. Odense (DK), 586-587.

Tamm, L. (2000) The impact of pests and diseases in organic agriculture. BCPC Conference Pests Dis 2000:159-165

Tomlin, C.D.S., 2000. (Ed.) The pesticide Manual, 12th ed.; BCPC: Farnham, U.K.; pp 828.

Ujvary, I. (2010) Pest Control Agent from Natural Products in: Krieger, R.I. [ Ed.] Handbook of Pesticide. Toxicology. 3th edition, ISBN: 978-0-12-374367-1, Academic Press, San Diego, 2010.

Valles, S. M. \& Capinera, J. L., 1993. Response of larvae of the southern armyworm, Spodoptera eridania (Cramer) (Lepidoptera: Noctuidae), to selected botanical insecticides and soap. J. Agr. Entomol., 10, 145-153.

Wheeler, G. S., Slansky, F., Yu, S. J. (2001) . Food consumption, utilization and detoxification enzyme activity of larvae of three polyphagous noctuid moth species when fed the botanical insecticide rotenone. Entomol. Exp. Appl., 98, 225-239.

Whitehead, D. L. \& Bowers, W. S., 1983. Natural Products for Innovative Pest Management, Pergamon Press, New York.

Willer, H. \& Lukas, K. (Eds.) (2011) The World of Organic Agriculture - Statistics and Emerging Trends 2011. IFOAM, Bonn and FiBL, Frick

Wink, M. (2006). Importance of plant secondary metabolites for protection against insects and microbial infections: In Rai M and Carpinella M.C. (eds). Naturally occurring bioactive compounds. Advances in phytomedicine, 3: 251-268.

www.endure-network.eu/.../French\%20NAP\%20-\%20Ecophyto\%202018.pdf 
Zander, K., Hamm, U., Freyer, B., Gössinger, K., Hametter, M., Naspetti, S., Padel, S., Stolz, H., Stolze, M. Zanoli, R. (2010) Farmer Consumer Partnerships- How to successfully communicate the values of organic food. A Handbook. Self-published, Department of Agricultural and Food Marketing, University of Kassel, Witzenhausen. ISBN 978-87-92499-08-0. 


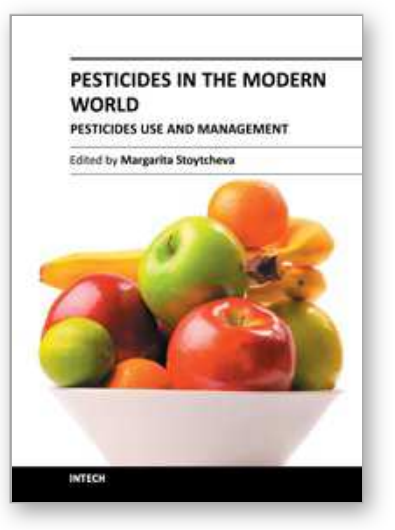

\author{
Pesticides in the Modern World - Pesticides Use and Management \\ Edited by Dr. Margarita Stoytcheva
}

ISBN 978-953-307-459-7

Hard cover, 520 pages

Publisher InTech

Published online 19, October, 2011

Published in print edition October, 2011

This book brings together issues on pesticides and biopesticides use with the related subjects of pesticides management and sustainable development. It contains 24 chapters organized in three sections. The first book section supplies an overview on the current use of pesticides, on the regulatory status, on the levels of contamination, on the pesticides management options, and on some techniques of pesticides application, reporting data collected from all over the world. Second section is devoted to the advances in the evolving field of biopesticides, providing actual information on the regulation of the plant protection products from natural origin in the European Union. It reports data associated with the application of neem pesticides, wood pyrolysis liquids and bacillus-based products. The third book section covers various aspects of pesticides management practices in concert with pesticides degradation and contaminated sites remediation technologies, supporting the environmental sustainability.

\title{
How to reference
}

In order to correctly reference this scholarly work, feel free to copy and paste the following:

Ivana Cavoski, Pierluigi Caboni and Teodoro Miano (2011). Natural Pesticides and Future Perspectives, Pesticides in the Modern World - Pesticides Use and Management, Dr. Margarita Stoytcheva (Ed.), ISBN: 978953-307-459-7, InTech, Available from: http://www.intechopen.com/books/pesticides-in-the-modern-worldpesticides-use-and-management/natural-pesticides-and-future-perspectives

\section{INTECH}

open science | open minds

\section{InTech Europe}

University Campus STeP Ri

Slavka Krautzeka 83/A

51000 Rijeka, Croatia

Phone: +385 (51) 770447

Fax: +385 (51) 686166

www.intechopen.com

\section{InTech China}

Unit 405, Office Block, Hotel Equatorial Shanghai

No.65, Yan An Road (West), Shanghai, 200040, China 中国上海市延安西路65号上海国际贵都大饭店办公楼 405 单元

Phone: +86-21-62489820

Fax: $+86-21-62489821$ 
(C) 2011 The Author(s). Licensee IntechOpen. This is an open access article distributed under the terms of the Creative Commons Attribution 3.0 License, which permits unrestricted use, distribution, and reproduction in any medium, provided the original work is properly cited. 